\title{
EXPORT CONTROLS: AMERICA'S OTHER NATIONAL SECURITY THREAT
}

\author{
CHAD P. BOWN*
}

The Trump administration's allegations that some imports are a threat to America's national security have received wide publicity during 2017-20. But the administration was undertaking a more quiet U.S. policy shift on the export side in the same time frame. Addressing the national security threat presented by exports posed different economic and institutional challenges from those associated with import policy, including the acknowledgment that export controls for legitimate national security reasons can be the first-best policy to address the problem at its source. Yet, export controls could also be misused as a beggar-thy-neighbor policy to redistribute economic wellbeing across countries, even from one ally to another. This paper describes how U.S. export control policy evolved over 2017-20, as well as the international institutions - first the Coordinating Committee for Multilateral Export Controls, then the Wassenaar Arrangement-historically tasked with multilateralizing U.S. export restrictions used to protect national security. With the potential for U.S. export control policy to brush up more frequently against World Trade Organization (WTO) rules designed to limit the use of export restrictions, the paper also highlights new challenges for the WTO's system of resolving trade disputes. Overall, a U.S. failure to strike the right balance for its export control policy would result in it being ineffective at addressing national security risks, costly for the economy, and problematic for trade and diplomatic relations.

I. INTRODUCTION 284

II. THE TRUMP ADMINISTRATION LINKS NATIONAL SECURITY, ECONOMIC SECURITY, AND TRADE POLICY 287

III. U.S. EXPANSION OF EXPORT CONTROLS UNDER EXISTING STATUTES DURING THE TRUMP-CHINA TRADE WAR 289

IV. MAJOR CHANGES TO U.S. LAW AND TO EXPORT CONTROL REGULATIONS BEGAN IN 2018 292

Copyright (C) 2020 Chad P. Bown

* Chad P. Bown is the Reginald Jones Senior Fellow at the Peterson Institute for International Economics in Washington, D.C. Thanks to Martin Chorzempa, Soumaya Keynes, Nicholas Lardy, Niall Meagher, and Marcus Noland for extremely useful discussions. All remaining errors are my own. 
V. COCOM AND MULTILATERAL EXPORT CONTROLS DURING THE COLD WAR 296

VI. THE WASSENAAR ARRANGEMENT AND MULTILATERAL EXPORT CONTROLS SINCE 1995 298

VII. GOVERNMENTS SOMETIMES LIMIT EXPORTS FOR POLITICAL OR ECONOMIC REASONS UNRELATED TO NATIONAL SECURITY 300

VIII. THE WTO RULES AND EXPORT CONTROLS 302

IX. WTO DISPUTE SETTLEMENT, NATIONAL SECURITY, AND EXPORT

RESTRICTIONS 304

X. CONCLUSION 307

\section{INTRODUCTION}

On January 6, 2020, the Trump administration announced new export controls on artificial intelligence (AI) software. For the first time, an American company would need to apply for a special license to sell satellite imagery software abroad ${ }^{1}$ and the U.S. government could deny the application, nixing any revenue from export sales.

That was not the end of it. On February 16, the Wall Street Journal reported that the administration was contemplating a ban on exports of jet engines to China for use in civil aircrafts. ${ }^{2}$ This threatened to cut off some of General Electric's jet engine sales to one of the world's largest and fastestgrowing markets for commercial aviation.

Then on February 17, the Wall Street Journal reported that the U.S. administration was considering a new rule to prohibit American companies from supplying equipment to foreign manufacturers of semiconductors that wanted it to make chips to sell to China. ${ }^{3}$ This could have curtailed hundreds of millions of dollars of U.S. sales to customers like Taiwan Semiconductor Manufacturing Company, one of the largest semiconductor foundries in the world.

As the rumors swirled, on February 18, President Donald Trump intervened, tweeting that America would remain open for business, and that the "United States cannot, \& will not, become such a difficult place to deal

1. The exception was that the software could be sold in Canada. See James Politi, US Proposes New Export Controls on Satellite Imagery Software, Fin. TIMES (Jan. 3, 2020), https://www.ft.com/content/2c07e5b0-2e5d-11ea-a126-99756bd8f45e; Kevin J. Wolf et al., A Look at New Limits on Geospatial Imagery Software Exports, LAw360 (Jan. 7, 2020), https://www.law360.com/ articles/1232040/a-look-at-new-limits-on-geospatial-imagery-software-exports.

2. Ted Mann \& Bob Davis, Trump Administration Considers Halting GE Venture's Engine Deliveries to China, WALl ST. J. (Feb. 16, 2020), https://www.wsj.com/articles/trump-administrationconsiders-halting-ge-ventures-engine-deliveries-to-china-11581790083.

3. Asa Fitch \& Bob Davis, U.S. Weighs New Move to Limit China's Access to Chip Technology, WALL ST. J. (Feb. 17, 2020), https://www.wsj.com/articles/u-s-weighs-new-move-to-limit-chinasaccess-to-chip-technology-11581942688. 
with in terms of foreign countries buying our product, including for the always used National Security excuse." He added, "I want China to buy our jet engines, the best in the World," a sentiment perhaps designed to comfort worried executives at General Electric. ${ }^{4}$ The Semiconductor Industry Association responded with temporary relief, applauding "President Trump's tweets supporting U.S. companies being able to sell products to China and opposing proposed regulations that would unduly curtail that ability."

Nevertheless, uncertainty persisted. The president's tweets have not historically been a guarantee of the path of policy, and in this instance were not enough to assuage those worried that further restrictions in the name of America's national security might be forthcoming. The whiplash around these events did little to clarify whether this was the beginning of a larger change in U.S. policy toward exports, and one with implications for tens of billions of dollars' worth of expected trade. And it was clearly not over when, in late March, additional reports swirled that the Trump administration was pushing ahead with export restrictions on semiconductor manufacturing equipment after all. ${ }^{6}$

Much of the call to action on export controls arose out of growing U.S. government concern with China. In 2018, with bipartisan support, Congress passed and President Trump signed into law the Export Control Reform Act of 2018. But its scope and scale remained unclear well after the statute went into effect. In part, this was because Congress left it to the Trump administration to interpret and put into practice two key elements of the new law. First, what were the "emerging and foundational technologies" to be restricted? And second, how to define what was "essential to the national security of the United States"?

4. Donald Trump (@realDonaldTrump), TwiTTER (Feb. 18, 2020, 10:29 AM), https://twitter.com/realDonaldTrump/status/1229790099866603521 ("The United States cannot, \& will not, become such a difficult place to deal with in terms of foreign countries buying our product, including for the always used National Security excuse, that our companies will be forced to leave in order to remain competitive. We want to sell product and goods to China and other countries. That's what trade is all about. We don't want to make it impossible to do business with us. That will only mean that orders will go to someplace else. As an example, I want China to buy our jet engines, the best in the World. I have seen some of the regulations being circulated, including those being contemplated by Congress, and they are ridiculous. I want to make it EASY to do business with the United States, not difficult. Everyone in my Administration is being so instructed, with no excuses. THE UNITED STATES IS OPEN FOR BUSINESS!").

5. Semiconductor Industry Association, SIA Statement on President Trump's Tweets Regarding Export Controls, SIA (Feb. 18, 2020), https://www.semiconductors.org/sia-statement-on-presidenttrumps-tweets-regarding-export-controls/.

6. Bob Davis \& Katy Stech Ferek, U.S. Moving Forward with Rule to Limit Chips to Huawei, WALL ST. J. (Mar. 26, 2020). 
It is not for this paper to assess the national security implications of individual technologies, nor to define what is in the national security interests of the United States. Rather, the purpose is to highlight the risks and unintended consequences of controls that might be poorly designed or badly implemented. Because intelligence-gathering and enforcement resources are scarce, prioritization matters. If everything is about national security, nothing is about national security.

There were reasons to be concerned. The Trump administration took an expansive view of what was "essential to the national security of the United States" when it used that justification to apply tariffs on imported steel and aluminum from America's allies in 2018. The president himself had politicized typically bureaucratic and legal export control decisions by using them as bargaining chips in trade negotiations with China. Furthermore, he is not known for careful consideration of economic expertise or of America's commercial interests when it comes to trade.

And there were large economic interests at stake. Take a suddenly ubiquitous technology like AI; over a short period, it had been adopted by banks for fraud detection, retail outlets for online customer support, Netflix for movie recommendations, and carmakers for autonomous vehicles. What would the new AI export controls announced in January 2020 portend for its seemingly limitless commercial applications?

Export controls defined too broadly would make the United States a less attractive place for companies to do their research, development, and production, which they might shift elsewhere. Equally worrisome was the continuing cloud of uncertainty about future U.S. export control policy. Would American companies hold back on R\&D and key investment decisions until it was resolved? Squelching innovation is costly-the competitiveness of the American economy would suffer, as would American workers and communities losing out from that economic activity no longer taking place locally.

The final risk was that President Trump's preference for unilateralism would make ineffective the U.S. export controls actually needed to address the most worrisome national security threats. Getting export controls to work at safeguarding national security would require multilateralism-other governments need to agree to also hold back supplies of comparable technologies. But cooperation was being challenged by rising levels of distrust that some countries would seek to restrict exports-alleging a national security threat when there was none - to achieve political-economic gain in a beggar-thy-neighbor form. Thus, the multilateral institutions tasked with facilitating and policing export controls were confronted with new pressures that threatened to disrupt the delicate balance among cooperative 
rule making, exceptions to protect national security, and effective dispute resolution when inevitable frictions arose.

\section{THE TRUMP ADMINISTRATION LINKS NATIONAL SECURITY, ECONOMIC SECURITY, AND TRADE POLICY}

Almost from inauguration day, the Trump administration tied together trade and national security in ways not seen in U.S. policy for decades. White House National Trade Council director Peter Navarro set the stage in early March 2017 with a high-profile speech implying that the U.S. trade deficit was a threat to American national security. ${ }^{7}$ The next month, the administration began two investigations under Section 232 of the Trade Expansion Act of 1962 into whether imports of steel and aluminum threatened national security. In August, it opened another inquest, under Section 301 of the Trade Act of 1974, into whether China's unfair trade practices worked to "undermine American manufacturing, services, and innovation." ${ }^{\prime}$ Finally, in December, the administration released its National Security Strategy blueprint, defining its America First policy with the mantra that "economic security is national security."

What had been mostly rhetoric in 2017 became concrete policy actions in 2018. Beginning in March, the administration imposed twenty-five percent tariffs on steel and ten percent tariffs on aluminum, affecting nearly fifty billion dollars of imports. Its Section 232 reports alleged that such imports were a threat to national security, despite the fact that most such imports were from Canada, NATO-allied countries in Western Europe, Japan, and South Korea. In May, the administration turned to the Section 232 statute again, launching a new investigation into whether $\$ 350$ billion of imported automobiles and parts posed a threat to American national security. This began a sustained period in which the president repeatedly threatened the European Union and Japan with additional national security tariffsthreats suddenly made credible with his restrictions on steel and aluminum. ${ }^{10}$

7. See Peter Navarro, White House Nat'1 Trade Council Dir., National Association for Business Economics Conference, Peter Navarro Remarks (Mar. 6, 2017) (transcript available at https://www.cspan.org/video/?424924-3/peter-navarro-outlines-trump-administrations-trade-policy-economic-policyconference).

8. Presidential Memorandum for the United States Trade Representative, WHITE HouSE, (Aug. 14, 2017), https://www.whitehouse.gov/presidential-actions/presidential-memorandum-united-statestrade-representative/.

9. White House, National Security Strategy of the United States 17 (Dec. 2017), https://www.hsdl.org/?abstract\&did=806478.

10. Nearly a year later, in May 2019, as the Mexican Senate was meeting in a ceremony to consider passage of the U.S.-Mexico-Canada Agreement on trade just negotiated with the President, Trump threatened to invoke the International Emergency Economic Powers Act and impose a twenty-five percent tariff on all goods imported from Mexico. His motivation was also not trade-related; Trump felt 
An important inflection point for U.S. policy came after the Trump administration released details of its unfair trade investigation of China. Made public were a long list of American grievances laying the groundwork for subsequent policy actions. ${ }^{11}$ Some concerns involved explicit Chinese policies, such as Beijing's Made in China 2025 industrial policy, rolled out in 2015, which identified ten priorities for sectoral advancement that the U.S. administration felt posed a direct threat to American technological leadership. ${ }^{12}$ Other complaints alleged covert Chinese policies, such as statesponsored cyberhacking, theft of industrial secrets, espionage for commercial (as opposed to intelligence-gathering) purposes, as well as predatory foreign investment and purchases to acquire advanced American technology. The administration essentially alleged that Beijing was pursuing a Chinese version of "economic security as national security."

The Trump administration's subsequent "trade war" with China focused on import-related policies to start. ${ }^{13}$ Beginning in July 2018, the administration rolled out a series of tariff actions that ultimately covered $\$ 360$ billion, or nearly two thirds, of U.S. imports from China by September $2019 .{ }^{14}$ Most of those imports faced additional U.S. tariffs of twenty-five percent and remained in place despite the administration's truce with China implemented in February 2020. ${ }^{15}$

Mexico was not doing enough to address the flow of migrants arriving from Central America. In the end, he backed down without imposing tariffs.

11. See OfFice of the U.S. Trade Representative, Findings of the InVESTigation Into China's Acts, Policies, and Practices Related to Technology Transfer, Intellectual Property, AND INNOVATION UNDER SECTION 301 of THE TRADE ACT of 1974, (Mar. 22, 2018) https://ustr.gov/about-us/policy-offices/press-office/press-releases/2018/march/section-301-reportchinas-acts (describing the Trump administration's frustrations with China's trade practices). See also OfFice of the U.S. TRAde Representative, Update Concerning China's ACts, Policies and Practices Related to TeChNOlogy Transfer, InTEllectual Property, AND INNOVATION, (Nov. 20, 2018), https://ustr.gov/about-us/policy-offices/press-office/press-releases/2018/november/ustrupdates-section-301 (explaining that China did not alter its trade practices, even after increased criticism from the Trump administration).

12. Press Release, Notice of the State Council on Printing and Distributing "Made in China 2025" (May 8, 2015), http://www.gov.cn/zhengce/content/2015-05/19/content_9784.htm. The ten industrial policy priorities included the next generation of information technology; robotics, artificial intelligence and automation; aerospace equipment; offshore engineering equipment and high-tech ships; advanced rail transportation equipment; new energy vehicles; power systems; agriculture machinery and equipment; advanced materials; and biomedicine and high-performance medical devices.

13. In addition to the tariffs, the administration filed a WTO dispute over Chinese laws and regulations that prevent foreign patent holders from being able to enforce their rights against a Chinese joint venture after a technology transfer contract ends. Request for Consultations by the United States, China-Certain Measures Concerning the Protection of Intellectual Property, WTO Doc. WT/DS542/1 (Mar. 26, 2018).

14. Chad P. Bown \& Melina Kolb, Trump's Trade War Timeline: An Up-to-Date Guide, PIIE (2020), https://www.piie.com/blogs/trade-investment-policy-watch/trump-trade-war-china-date-guide.

15. Chad P. Bown, Phase One China Deal: Steep Tariffs Are the New Normal, PIIE (2019), 
The president made clear in a March 2018 memorandum that the United States would ultimately deploy policies in addition to import tariffs as part of the trade war. ${ }^{16}$ In a section on potential restrictions on Chinese investment, for example, the president directed his administration to consider "any available statutory authority, to address concerns about investment in the United States directed or facilitated by China in industries or technologies deemed important to the United States." Thus, it was not surprising when the administration turned to other U.S. statutes, including those allowing the government to control what American companies could export to China.

The tariff decisions signaled a major shift in U.S. policy toward imports. Yet, on export control policy, some of the president's subsequent actions still caught many by surprise.

\section{U.S. EXPANSION OF EXPORT CONTROLS UNDER EXISTING STATUTES DURING THE TRUMP-CHINA TRADE WAR}

U.S. export controls were one important example of President Trump's periodically injecting other policies into the mix during the first two years of his trade war with China. The primary initial targets of U.S. export restrictions were Chinese telecommunications giants ZTE and Huawei. These companies faced the threat of lost access to American-made semiconductors, software, and other technologies on which they relied for production for sale in China and other foreign markets.

Preceding the trade war, in March 2017, ZTE had agreed to a settlement with the U.S. government for its failure to abide by U.S. sanctions prohibiting the sale of certain technology to Iran and North Korea. ZTE's agreement to plead guilty, pay a fine, and change some of its internal practices followed a multi-year investigation brought under the Obama administration; while serious, the settlement was received as relatively routine and apolitical. ${ }^{17}$ That perception began to change when, on April 15, 2018, the U.S. government enacted a denial order against ZTE that would have resulted in export controls for the company's violation of the terms set

https://www.piie.com/blogs/trade-and-investment-policy-watch/phase-one-china-deal-steep-tariffs-arenew-normal.

16. For specifics, see The White House, Presidential Memorandum on the Actions By the United States Related to THE SeCtion 301 InVESTigation (2018), https:/www.whitehouse.gov/ presidential-actions/presidential-memorandum-actions-united-states-related-section-301-investigation (describing the policy responses the United States would take in light of its Section 301 investigation of China).

17. Aruna Viswanatha, Eva Dou \& Kate O’Keeffe, ZTE to Pay $\$ 892$ Million to U.S., Plead Guilty in Iran Sanctions Probe, WALL ST. J. (Mar. 7, 2017), https:/www.wsj.com/articles/zte-to-pay-892million-to-u-s-plead-guilty-in-iran-sanctions-probe-1488902019. 
out in the March 2017 agreement. ${ }^{18}$ But in a surprising move, President Trump brought the export controls levied on ZTE directly into his trade war negotiations with President Xi Jinping. Trump overruled his Commerce Department's denial order and demanded the department negotiate a settlement to lift the export controls and restore ZTE's access to Americanmade goods and services. ${ }^{19}$

Huawei faced a separate set of actions during the trade war. In May and August 2019, the U.S. government alleged that Huawei and a number of its affiliate companies were involved in "violations of the International Emergency Economic Powers Act (IEEPA), conspiracy to violate IEEPA by providing prohibited financial services to Iran, and obstruction of justice in connection with the investigation of those alleged violations of U.S. sanctions." ${ }^{20}$ Huawei was thus added to the "entity list" of companies that were required to receive a license to obtain any product subject to existing U.S. export controls.

The controls - and threats of more - heightened awareness at ZTE and Huawei, as well as in the Chinese government, of the companies' vulnerabilities. Cutting off access to American exports of semiconductors, software, and related technologies could have been devastating, putting tens of thousands of Chinese out of work. Thus, one unintended consequence of the Trump administration's policy may have been for Beijing to pursue an even more aggressive approach to industrial policy. The fear of being cut off could have created the incentive to speed up diversification of its supplier base, perhaps with the Chinese government increasing its already considerable state support for domestic semiconductors. ${ }^{21}$

18. Paul Mozur and Ana Swanson, Chinese Tech Company Blocked from Buying American Components, N.Y. TIMES (Apr. 16, 2018), https://www.nytimes.com/2018/04/16/technology/chinesetech-company-blocked-from-buying-american-components.html.

19. See Donald J. Trump (@realDonaldTrump), TwitTer (May 13, 2018, 11:01 AM), https://twitter.com/realDonaldTrump/status/995680316458262533 ("President Xi of China, and I, are working together to give massive Chinese phone company, ZTE, a way to get back into business, fast. Too many jobs in China lost. Commerce Department has been instructed to get it done!").

20. Press Release, Dep't of Commerce, Department of Commerce Announces the Addition of Huawei Technologies Co. Ltd. to the Entity List (May 15, 2019), https://www.commerce.gov/news/pressreleases/2019/05/department-commerce-announces-addition-huawei-technologies-co-ltd; Press Release, Dep't of Commerce, Department of Commerce Adds Dozens of New Huawei Affiliates to the Entity List and Maintains Narrow Exemptions through the Temporary General License (Aug. 19, 2019), https://www.commerce.gov/news/press-releases/2019/08/department-commerce-adds-dozens-newhuawei-affiliates-entity-list-and (describing the addition of more Huawei Affiliates to the Entry List).

21. See generally Organisation for Economic Co-operation and Development [OECD], Measuring Distortions in International Markets: The Semiconductor Value Chain, OECD Trade \& Agriculture Directorate, TAD/TC(2019)9/FINAL, (Nov. 21 2019), http://www.oecd.org/officialdocuments/ publicdisplaydocumentpdf/?cote $=$ TAD/TC(2019)9/FINAL\&docLanguage $=$ En $($ describing the OECD's investigation into disruptions in semiconductor markets). 
The U.S. administration's export control actions also revealed some immediate costs to American businesses of being cut off from Chinese buyers. Google's Android would lose out if Huawei chose other operating systems for its smartphones. ${ }^{22}$ Qualcomm, Acacia Communications, and other American companies suffered hits to their stock prices when markets discovered that ZTE could be forced to stop purchasing American-made technologies. ${ }^{23}$

Nevertheless, the March 2020 revelation that the administration was still considering an extension of U.S. export controls to semiconductor manufacturing equipment was a major potential escalation. ${ }^{24}$ Despite the President's February 18 tweets, the Trump administration seemed intent on going ahead with a modification to something called the "direct product rule," that would attempt to extend the reach of U.S. controls to other countries' suppliers seeking to make sales to Huawei.

For example, the policy affects non-Chinese semiconductor companies like Taiwan Semiconductor Manufacturing Company (TSMC), which had considerable sales to Huawei. ${ }^{25}$ The proposed U.S. export controls were reportedly designed to confront a company like TSMC with a choice: To retain access to U.S. equipment, TSMC would have to give up its sales to Huawei of chips made using that equipment; alternatively, TSMC could keep its Huawei business, but it would need to switch from American-made to semiconductor manufacturing equipment produced by firms in South Korea, Japan, or elsewhere.

The proposed export controls were a bet that companies like TSMC would choose continued access to American equipment over their future sales to Huawei. But what if they did not? TSMC's decision would also depend, of course, on the availability of substitute equipment from nonAmerican suppliers. And that availability would hinge on whether the U.S. export control would be multilateralized, so that other exporting countries applied it too. In this example, the South Korean and Japanese governments would need to impose controls on their equipment suppliers' sales to firms like TSMC.

A failure to get U.S.-imposed controls multilateralized to other

22. Yang Jie \& Dan Strumpf, Who Needs Google's Android? Huawei Trademarks Its Own Smartphone OS, WALL ST. J. (May 25, 2019), https://www.wsj.com/articles/who-needs-googles-androidhuawei-trademarks-its-own-smartphone-os-11558693195.

23. Jay Greene, In ZTE Battle, U.S. Suppliers Are Collateral Damage, WALl ST. J. (Apr. 24, 2018), https:/www.wsj.com/articles/in-zte-battle-u-s-suppliers-are-collateral-damage-1524562201.

24. Asa Fitch \& Bob Davis, U.S. Chip Industry Fears Long-Term Damage From China Trade Fight, WALL ST. J. (Mar. 9, 2020), https://www.wsj.com/articles/chip-industry-fears-damage-china-trade-fight11583693926.

25. Fitch \& Davis, supra note 3. 
countries would potentially be devastating for the U.S. semiconductor industry. Its fears were described in a March 2020 study commissioned by the Semiconductor Industry Association. ${ }^{26}$ The study imagined a scenario in which a U.S. policy of the sort reported in February 2020 was a bad bet; i.e., that unilateral U.S. export controls would result in many foreign companies choosing to engage with China instead of the United States for equipment and input sourcing. The study estimated the cost to the U.S. industry at tens of billions of dollars of annual revenue - revenue that was the main source of research and development (R\&D) funding needed for American companies' next generation of chips. Because less R\&D would make the next round of American semiconductors less competitive globally, future customers would be even less likely to choose U.S. equipment and inputs. The study pointed to a vicious cycle of American industrial decline, with the pain extending to American workers at these companies and their communities reliant on the jobs and economic activity supported by the industry.

\section{MAJOR CHANGES TO U.S. LAW AND TO EXPORT CONTROL REGULATIONS BEGAN IN 2018}

In the midst of the trade war and the battle with ZTE in 2018, the U.S. government undertook a separate legislative process to overhaul its export control regime. The debate between Congress and the Trump administration involved a number of proposals, some even more far-reaching than the final legislation. ${ }^{27}$ Nevertheless, the new statute had the potential to severely curtail U.S. exports for products that might have "dual use" (both military and commercial application). The Export Control Reform Act of 2018 (ECRA) came into law on August 13, 2018 as part of the John S. McCain National Defense Authorization Act. It was passed with bipartisan support of 87 votes in the Senate and 351 votes, including 131 Democrats, in the House of Representatives.

26. See John Neuffer, Report Shows Risks of Excessive Restrictions on Trade with China, SIA (Mar. 09, 2020), https://www.semiconductors.org/report-shows-risks-of-excessive-restrictions-on-trade-withchina/ (explaining a report made by the Boston Consulting Group which discussed the adverse impact of restricting trade with China on the United States' semiconductor position). See also Antonio Varas \& Raj Varadarajan, How Restricting Trade with China Could End US Semiconductor Leadership, BosTON CONSUlTING GROUP (Mar. 09, 2020), https://www.bcg.com/publications/2020/restricting-trade-withchina-could-end-united-states-semiconductor-leadership.aspx (describing the adverse impact of restricting trade with China on the United States' semiconductor position).

27. For more on the debated proposals, see Wolf et al., supra note 1; Martin Chorzempa \& Gary C. Hufbauer, Trump Awaits Congress on Investment and Technology Controls, PIIE (Jul. 9, 2018), https://www.piie.com/blogs/trade-investment-policy-watch/trump-awaits-congress-investment-andtechnology-controls. 
To many, the ECRA was long overdue. ${ }^{28}$ It codified existing U.S. government practices into law by replacing executive orders that had been issued annually under the IEEPA since the statutory authority for the Export Administration Regulations (EARs) set up by the Export Administration Act of 1979 lapsed in 2001.

But ECRA also had the potential to do much more. Under the law, Congress tasked the Bureau of Industry and Security (BIS) in the Department of Commerce to update U.S. export controls on "emerging and foundational technologies" that were "essential to the national security of the United States." BIS would lead an ongoing interagency process to identify and add products to the EARs. To fulfill its very challenging new mandate, BIS eventually requested additional budgetary resources from Congress. ${ }^{29}$

In the implementing regulations to guide the process, BIS came up with fourteen new categories of representative technologies for which it sought public input into whether to implement new export controls and, if so, how far-reaching they should be. ${ }^{30}$ New limits would be considered for goods and services such as AI, machine learning, quantum computing, and 3D printing. In seeking to define the specific emerging and foundational technologies to control, BIS established technical advisory committees "composed of representatives from industry, academia, and the U.S. Government and reflect[ing] diverse points of view on the concerns of the exporting community." 31

The American business community was nonetheless concerned that the BIS scoping exercise would be indifferent to its input. Billions of dollars of R\&D expenditures had been premised on access to foreign markets, and more expansive export restrictions could hamper the expected commercial

28. The Obama administration had attempted a reform of U.S. export controls, but it was never implemented into law. For a discussion on the reform attempts, see generally IAN F. FERGUSSON \& PAUL

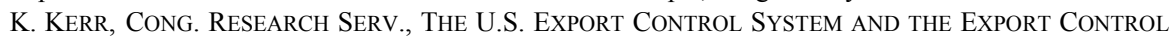
REFORM INITIATIVE (Jan. 28, 2020), https://fas.org/sgp/crs/natsec/R41916.pdf.

29. Commerce Requests 8 Percent BIS Funding Hike to Counter China's Tech Rise, INSIDE US TRADE (Feb. 12, 2020), https://insidetrade.com/daily-news/commerce-requests-8-percent-bis-fundinghike-counter-china $\% \mathrm{E} 2 \% 80 \% 99$ s-tech-rise.

30. Review of Controls for Certain Emerging Technologies, A Proposed Rule by the Industry and Security Bureau on 11/19/2018, 83 Fed. Reg. 58201, https:/www.federalregister.gov/documents/ 2018/11/19/2018-25221/review-of-controls-for-certain-emerging-technologies. These fourteen categories were biotechnology; artificial intelligence and machine learning technology; position, navigation, and timing technology; microprocessor technology; advanced computing technology; quantum information and sensing technology; logistics technology; additive manufacturing (e.g., 3D printing); robotics; brain-computer interfaces; hypersonics; advanced materials; and advanced surveillance technologies.

31. Technical Advisory Committees; Notice of Recruitment of Members, A Notice by the Industry and Security Bureau on 04/01/2019, 84 Fed. Reg. 12195, https://www.federalregister.gov/documents/ 2019/04/01/2019-06239/technical-advisory-committees-notice-of-recruitment-of-members. 
benefits. ${ }^{32}$ As Kevin Wolf, who directed U.S. export control policy as former Assistant Secretary of Commerce for Export Administration in the Obama administration, said in testimony before the Senate Banking Committee almost a year after the new law went into effect, "many are wondering what the impact on their businesses will be and how BIS will justify any new controls based on the ECRA standards." 33

Uncertainty over the commercial implications of new U.S. export control policy increased with the activity and reports of January and February 2020. U.S. government concerns with ZTE and Huawei were longstanding and predated the Trump administration. But these events signaled something new.

The January 6 announcement of new export controls on satellite imagery software, for example, was significant because AI was on the BIS list of "emerging and foundational technologies" under examination. The first control on AI exports seemed narrow, but was it just a start?

Autonomous vehicles were another example of a product for which AI was critical. ${ }^{34}$ Fears that the United States would attempt to control AI for self-driving cars were reportedly impacting joint ventures between American and Chinese startups, as well as their access to funding. ${ }^{35}$

More generally, economists Kyle Handley and Nuno Limão have documented evidence from a variety of settings showing that uncertainty over foreign market access due to import tariffs can hamper investment, production, and exports. ${ }^{36}$ Changes in U.S. export control policy provided

32. See Martin Chorzempa, The Trump Administration's Rush to Curb Technology Leakage Is in Danger of Backfiring, TRADE \& INV. POL'Y WATCH BLOG (Jan. 8, 2019), https://www.piie.com/blogs/trade-investment-policy-watch/trump-administrations-rush-curbtechnology-leakage-danger (describing the Trump administration's controls on exports of emerging technologies deemed "essential to national security"); Martin Chorzempa, Worst Case Averted on Foreign Investment Reviews, TRADE \& INV. POL'Y WATCH BLOG (Aug. 20, 2018), https://www.piie.com/ blogs/trade-investment-policy-watch/worst-case-averted-foreign-investment-reviews (explaining the national security effects of the John S. McCain National Defense Authorization Act For Fiscal Year 2019).

33. Confronting Threats from China: Assessing Controls on Technology and Investment: Testimony before the S. Comm. on Banking, Housing, \& Urban Affairs, 116th Cong. 13 (June 4, 2019) (Hon. Kevin Wolf, Partner, Akin Gump Strauss Hauer \& Feld LLP), https://www.banking.senate.gov/ imo/media/doc/Wolf\%20Testimony\%206-4-19.pdf.

34. For important early research on AI and international trade and potential implications for policy, see Avi Goldfarb \& Daniel Trefler, Artificial Intelligence and International Trade, in THE ECONOMICS of ARTIFiCIAL INTELLigENCE: AN AGENDA 463-92, 463 (Ajay Agrawal et al. eds., 2019).

35. Trefor Moss, U.S.-China Trade Tensions Jeopardize Rollout of Self-Driving Vehicles, WALL ST. J. (Sept. 24, 2019), https://www.wsj.com/articles/u-s-china-trade-tensions-risk-rollout-of-selfdriving-vehicles-11569326403.

36. See generally Kyle Handley \& Nuno Limão, Trade Under T.R.U.M.P. Policies, in ECONOMICS AND POLICY IN THE AGE OF TRUMP 141-52 (Chad P. Bown ed., 2017) (discussing how President Trump's increase in the United States's import barriers could damage the credibility of the world trading system). 
one more channel by which costs of elevated levels of uncertainty might impact American-based businesses.

Finally, as one other central part of ECRA, Congress mandated that BIS ensure the multilateral adoption of any new U.S. controls, noting that unilateral U.S. export controls on "widely available" goods would be ineffective. ${ }^{37}$ ECRA indicated that if the administration did not succeed in getting a particular control adopted by other countries within three years, the U.S. government should drop it. ${ }^{38}$

This multilateralization requirement mattered for both national security and commercial reasons. A control would do little to safeguard U.S. national security if the equivalent technology were available on global markets from other foreign suppliers. And American companies would be hurt commercially if they were the only ones unable to sell it.

But getting other key national governments to adopt any new U.S. export control required international cooperation. Understanding how to work the multilateral process was fundamental if the United States was to considerably expand the scope of its export controls. ${ }^{39}$

37. Export Control Reform Act of 2018, Pub. L. No. 115-232, § 4811(6), 132 Stat. 2210 (2018) ("Export controls applied unilaterally to items widely available from foreign sources generally are less effective in preventing end-users from acquiring those items. Application of unilateral export controls should be limited for purposes of protecting specific United States national security and foreign policy interests.").

38. In particular, Section 1758(c), Requirements to Identify and Control the Export of Emerging and Foundational Technologies, of the Export Control Reform Act of 2018, Pub. L. No. 115-232, 132 Stat. 2208, 2221 (2018) states:

(C) Multilateral Controls.-

(1) In General.- The Secretary of State, in consultation with the Secretary and the Secretary of Defense, and the heads of other Federal agencies, as appropriate, shall propose that any technology identified pursuant to subsection (a) be added to the list of technologies controlled by the relevant multilateral export control regimes.

(2) Items On Commerce Control List Or United States Munitions List.-If the Secretary of State proposes to a multilateral export control regime under paragraph (1) to add a technology identified pursuant to subsection (a) to the control list of that regime and that regime does not add that technology to the control list during the 3-year period beginning on the date of the proposal, the applicable agency head may determine whether national security concerns warrant the continuation of unilateral export controls with respect to that technology.

39. The Trump administration's poor record of engaging in, as opposed to disrupting, other multilateral initiatives presents a particular challenge for international cooperation. The Trump administration's destructive acts toward the multilateral trading system and WTO are one example. See Chad P. Bown \& Soumaya Keynes, Why Trump Shot the Sheriffs: The End of WTO Dispute Settlement 1.0, at 2 (PIIE, Working Paper 20-4, Mar. 2020), https://www.piie.com/system/ files/documents/wp204.pdf (describing how the Trump administration's policy effectively ended the WTO's dispute resolution system). Other destructive acts include pulling out of the Paris Climate Accord and the Joint Comprehensive Plan of Action (JCPOA) for Iran sanctions. See Editorial, Where's the Better Deal, Mr. Trump?, N.Y. TIMES (May 8, 2018), https://www.nytimes.com/2018/05/08/opinion/iran-deal-trumpwithdraw.html (criticizing President Trump's decision to renege on the Iran nuclear deal using comparisons to the withdrawal from the Paris climate agreement). 
Some of the problems that arose with prior multilateralization of U.S. export controls provided clues as to where challenges might be expected.

\section{COCOM AND MULTILATERAL EXPORT CONTROLS DURING THE COLD WAR}

How the United States would convince other countries to adopt more stringent export controls was not, of course, an entirely new question. The origins of the modern approach date to shortly after the Second World War, as a response to growing tensions that the United States and its Western European allies had with the Soviet Union. The fear was that the Soviet Union would improve its military capabilities through acquisition of western equipment and commercial technologies that might have dual use, fears that intensified over the following forty years of the Cold War.

The allies negotiated the Coordinating Committee for Multilateral Export Controls (COCOM), which went into effect on January 1, 1950. The original members were the United States, United Kingdom, France, Italy, Belgium, the Netherlands, and Luxembourg ${ }^{40}$ with the exception of Iceland, members of the North Atlantic Treaty Organization (NATO) all joined over the following years.

COCOM was very different from other agreements affecting international commerce developed in parallel, most notably the General Agreement on Tariffs and Trade (discussed below). COCOM was not treatybased; it was an informal agreement that was established in secret and did not create binding legal obligations on the countries involved. Consensus drove decision-making, which also meant that any country had a veto. An export control arose by agreeing to place a product on one of three lists. The first two lists concerned international munitions and atomic energy. For export control purposes, products on these lists faced an embargo. ${ }^{41}$

The third list, involving dual-use technologies, was referred to as the International List, and its products were subject to export control review as opposed to bans. Products on this list could be exported subject to a licensing

40. Cindy Whang, Undermining the Consensus-Building and List-Based Standard in Export Controls: What the United States Export Controls Act Means to the Global Export Control Regime, $22 \mathrm{~J}$. INT'L ECON. L. 579, 584. (2019). Furthermore, when the Korean war broke out in 1950 and Chinese troops became involved, the United States pushed for COCOM to also apply its export controls toward China. They eventually did, and for the next four decades, the relative restrictiveness of the export control regime with respect to the Soviet Union and China shifted back and forth, based on political developments. For a discussion, see Hugo MeiJer, Trading with the EnEmy: The Making of US EXPort CONTRol Policy toward the PeOple’s Republic of China 33-54 (2016).

41. Over the second half of the twentieth century, other agreements emerged that banned exports of specific types of military goods, including chemical and biological weapons (Australia Group), nuclear weapons (Nuclear Suppliers Group), and missiles (Missile Technology Control Regime). 
requirement. Frequent debate emerged between COCOM countries over whether to add a new product to the International List, and the United States was often keener than the European members. The geographic proximity of the European allies to Eastern Europe and the Soviet Union-and their Warsaw Pact alliance - meant that the average export control had a greater impact on European foreign commercial interests.

On occasion, COCOM debates did escalate into conflict. Most notable was a 1980s dustup involving exports of submarine technology from Japan and Norway to the Soviet Union. In what became known as the ToshibaKongsberg Incident, a Japanese and Norwegian firm were charged with falsifying documents and evading government controls to export quiet submarine propellers to the Soviet fleet to help it evade Western sonar capabilities. ${ }^{42}$ Each company was sanctioned by its government, but a new debate emerged within the U.S. government as to the appropriate American policy response. The Congress was furious that it might have to allocate hundreds of millions of dollars of additional military funding to address the new national security threat caused by Soviet acquisition of the sonarevading propellers. It proposed legislation, the Garn Amendment, that would have slapped U.S. sanctions on Toshiba and Kongsberg.

The Reagan administration pushed back against congressional demands for additional U.S. penalties beyond those imposed by the Norwegian and Japanese governments. One administration concern was that the sanctions might cripple Toshiba's ability to fulfill its contracts, hurting American consumers and suppliers to the companies. But another worry was that additional U.S. punishment could have systemic implications for COCOM itself: COCOM was voluntary, and even allied governments might choose to pull out if penalties for violating rules on export controls became excessive.

This incident highlighted the trade-offs that any multilateral export control regime must navigate. The lack of multilateral controls meant that one country's (the United States') unilateral export restriction was insufficient to protect national security (i.e., the target country acquired the technology). But allowing for excessive punishment of parties that violated the agreement could have resulted in reduced engagement and cooperation overall.

42. See generally Jere W. Morehead, Controlling Diversion: How Can We Convert the ToshibaKongsberg Controversy into a Victory for the West, 9 NE. J. INT'L L. \& BUS. 277 (1988) (discussing how the West could benefit from the Toshiba-Kongsberg controversy); Wende A. Wrubel, The ToshibaKongsberg Incident: Shortcomings of Cocom, and Recommendations for Increased Effectiveness of Export Controls to the East Bloc., 4 AM. U. INT'L. L. REV. 241 (discussing the Toshiba-Kongsberg incident). See also David E. Sanger, U.S. Changes Its Stance on Damage by Toshiba, N.Y. TIMES, (Mar. 14, 1988), https://www.nytimes.com/1988/03/14/business/us-changes-its-stance-on-damage-bytoshiba.html (discussing the history of the Toshiba-Kongsberg incident). 


\section{THE WASSENAAR ARRANGEMENT AND MULTILATERAL EXPORT CONTROLS SINCE 1995}

COCOM was dissolved with the end of the Cold War in 1994, and a new form of multilateral cooperation emerged to take its place. In 1995, the Wassenaar Arrangement was established with thirty-three members as the new, multilateral vehicle for export controls. Importantly, it included Russia, which, as part of the Soviet Union, had obviously been a main target of the COCOM export control efforts. ${ }^{43}$ While participation in the Wassenaar Arrangement expanded to forty-two countries by 2020, China remained a major nonparticipant. ${ }^{44}$ The European Union was also not a formal participant, despite engagement by E.U. member states in their national capacities.

The Wassenaar Arrangement followed the COCOM model in only some respects. It continued to be based on voluntary submissions of products that countries wanted to control. However, it prioritized transparency and shifted its focus to nonproliferation. To do so, it maintained two lists. The first was the Munitions List and covered conventional arms, including rifles, handguns, machine guns, submachine guns, bombs, torpedoes, rockets, and missiles. The second list of Dual-Use Goods and Technologies, was where more commercial concerns arose. It covered nine categories: special materials and related equipment, materials processing, electronics, computers, telecommunications and information security, sensors and lasers, navigation and avionics, marine, and aerospace and propulsion. ${ }^{45}$

A good or service was to be evaluated against four criteria before being subject to the dual-use list for export control. First, there was little utility in subjecting an export to restraints if it was already available from countries that did not participate in the Wassenaar Arrangement. Second, countries were discouraged from proposing limits on products where the restriction

43. Wassenaar Arrangement on Export Controls for Conventional Arms and Dual-Use Goods and Technologies, Vol. I, Founding Documents, Dec. 19, 1995, WA-DOC (17) PUB 001, https://www.wassenaar.org/app/uploads/2019/consolidated/WA-DOC-17-PUB-001-Public-Docs-Vol-IFounding-Documents.pdf.

44. The Wassenaar Arrangement has periodically engaged in "outreach activities" to nonparticipating states, including China. See, e.g., Wassenaar Arrangement on Export Controls for Conventional Arms and Dual-Use Goods and Technologies, Vol. IV: Background Documents and Plenary-related and Other Statements, WA-DOC (19) PUB 006 (compiled Dec. 2019), https://www.wassenaar.org/app/uploads/2019/12/WA-DOC-19-PUB-006-Public-Docs-Vol-IV-

Background-Docs-and-Plenary-related-and-other-Statements-Dec.-2019.pdf.

45. For the lists as of December 2019, see List of Dual-Use Goods and Technologies and Munitions List, Wassenaar Arrangement on Export Controls for Conventional Arms and Dual-Use Goods and Technologies, Wa-List (19) (Dec. 5, 2019), https://www.wassenaar.org/app/uploads/2019/12/WA-DOC19-PUB-002-Public-Docs-Vol-II-2019-List-of-DU-Goods-and-Technologies-and-Munitions-List-Dec19.pdf. 
would knowingly not work. Third, product definitions should include a "clear and objective specification"; broad descriptions would catch commercial items for which controls were unnecessary. And finally, the product should not be already controlled by some other regime (e.g., the Munitions List or the Nuclear Suppliers Group). ${ }^{46}$

Nevertheless, a potentially more expansive U.S. export control policy suggested at least three areas of tension with the Wassenaar Arrangement framework.

First, the modern pace of technological change posed an immense challenge to any control regime. Consider an attempt to control semiconductors. According to Moore's Law, the number of transistors on a chip doubles about every two years. A controlled technology today could become a potential commodity item tomorrow. Such a fast pace of innovation raised the concern that BIS could not possibly evaluate and multilateralize controls for new products quickly enough-i.e., before the technology became widely distributed.

A second concern involved the breadth of new export controls. Some emerging and foundational technologies under the U.S. review process did not naturally fit under the nine Wassenaar Arrangement categories. Furthermore, the Wassenaar criterion of an item having a "clear and objective specification" could run afoul of U.S. attempts to introduce more general classifications of products it wanted to control.

Finally, an asymmetry remained between the potential targets of U.S. controls - which might include China - and those agreed multilaterally. The traditional focus of the Wassenaar Arrangement had been on nonproliferation and keeping controlled items away from rogue states. Thus, any U.S. attempt to get partners to control a technology with respect to a certain country (e.g., China) would require additional bilateral engagement outside of Wassenaar with the other key suppliers.

For example, recall the Trump administration proposal to stop granting GE a license to sell commercial jet engines to China. ${ }^{47}$ For this control to protect national security, BIS would have needed to convince the governments of competing engine makers - e.g., Rolls Royce — to similarly deny such export licenses from their jurisdictions. Failure to convince the U.K. government would have left GE at a commercial disadvantage relative

46. Criteria for the Selection of Dual-Use Items, Wassenaar Arrangement on Export Controls for Conventional Arms and Dual-Use Goods and Technologies (adopted in 1994, amended by the Plenary in 2004 and 2005), https://www.wassenaar.org/app/uploads/2019/consolidated/Criteria_for_selection_ du_sl_vsl.pdf.

47. Ted Mann \& Bob Davis, Trump Administration Considers Halting GE Venture's Engine Deliveries to China, WALL ST. J. (Feb. 16, 2020). 
to its global competitors.

Overall, the consensus nature of the Wassenaar Arrangement, as well as potentially divergent economic interests among its participating countries, posed a challenge for U.S. unilateralism, and thus an effective export control policy. It would turn out to be much more difficult to multilateralize U.S. export control priorities than even during the Cold War-the last time such controls for dual-use items were put to such a stringent multilateral test.

\section{GOVERNMENTS SOMETIMES LIMIT EXPORTS FOR POLITICAL OR ECONOMIC REASONS UNRELATED TO NATIONAL SECURITY}

Any U.S. export control would be effective only if adopted multilaterally and if the technology were not already widely-available from non-controlled sources. One challenge for rulemaking was thus already clear: allied trading partners may not have commercial incentives to sign on to the United States' additional controls. U.S.-made jet engines vacating the Chinese market would pave the way for additional sales from Rolls Royce, for example. This posed one challenge to cooperation.

But there was a separate problem. Even allied governments suspected that the true motive behind U.S. efforts to restrict exports was economic or political (redistributive) gain at their expense. A quick tour through a simple, hypothetical economic model clarifies why a country can have incentives to abuse the national security threat justification for its export restrictions and why partners are wise to be skeptical.

Take the example of the United States being a "large" global supplier of semiconductor-making equipment. Being large simply means that a change in the level of U.S. exports affects the world price of the equipment. If it increases supply, the price in the rest of the world falls; if the United States limits supply, the world price increases.

Now assume that a legitimate national security threat exists and a "negative externality" arises: The United States and other countries experience social costs not taken into consideration by commercial actors (similar to the impacts of cross-border pollution or climate change) - but only if the equipment is traded. No extra social costs result from local U.S. production or consumption, but something bad happens if the equipment is sold abroad. In this instance, the standard Pigouvian economic logic for policymakers holds: the first-best government policy is to attack the externality at its source and limit equipment exports. If the negative externality of the national security threat is large enough, the first-best policy 
could even be a complete export ban. ${ }^{48}$

But now suppose there is no legitimate national security threat to trading the equipment. The concern is that the United States may sometimes benefit from restricting exports of the equipment anyway. The wariness of trading partners arises because this benefit occurs at their expense.

But why might the United States impose an export restriction when there is no national security threat? Limiting foreign sales means more is kept locally, with American consumers (e.g., the U.S. semiconductor chip industry) enjoying lower prices and increased equipment availability. However, the reduction in how much the U.S. equipment industry can sell globally and the lower prices for domestic sales result in a loss to the industry's economic well-being. Overall, losses to American equipment makers are larger than the gains to U.S. consumers. ${ }^{49}$ Even so, the U.S. government might implement an export restriction for political reasons-for example, because it values the well-being of the U.S. semiconductor chip industry (consumers) more than that of the equipment makers (producers).

Nevertheless, any benefit to the United States arising through the export restriction comes at the expense of its trading partners. Limiting U.S. equipment exports increases the price to foreign consumers (semiconductor companies like TSMC), hurting them more than the benefits to the rest of the world's equipment makers (in Japan or South Korea). Similar to the more familiar example of a large consuming country imposing a small import tariff, the U.S. export restriction here is therefore a beggar-thy-neighbor policy. $^{50}$

Beyond political motives, there may be additional economic incentives pushing the U.S. government to impose such restrictions. As one last tweak,

48. This would likely be the argument of those proposing the restriction of exports to China-i.e., that China's access to technology allows its industry to develop and this in itself poses a national security threat to the United States. Again, it is not for this paper to assess the national security implications of any individual technology or industry.

49. For the country as a whole, a small export restriction imposed as a tax can make total American wellbeing (consumers, producers, and the government combined) higher than free trade. But this is contingent on the receipt of tax revenue. An export control that prevents a product from being exported altogether is a quantitative restriction — or a quota — with the volume limit set at zero. More generally, the licensing procedure associated with export controls (even if all applications for export are accepted) are a non-tariff barrier. They impose additional compliance costs to firms that are similar to a tax, but in which the government collects no tax revenue.

50. See, e.g., Kyle Bagwell \& Robert W. Staiger, The ECONOMics of THE World Trading SYSTEM 57 (2002) (discussing the reciprocal nature of trade policy). Note, the simplest example that a country can be slightly better off with a unilateral export tax relative to free trade relies on the collection of tax revenue. An export control—either a ban or a non-tariff barrier evoking compliance costs-will not generally make a large supplying country better off. Nevertheless, a large country that imposes an export control for political or distributional reasons will still pass off some of the cost of that policy onto trading partners. 
suppose the consumers in the model - the semiconductor industry-are themselves producers and their industry benefits from increasing returns to scale. Because of learning by doing, each additional unit that the domestic industry produces allows it to lower its average costs. In that case, the U.S. export restriction on equipment generates a separate channel through which the American consumer (the semiconductor industry) benefits at the expense of its competitors in the rest of the world. The export restriction means firms, like TSMC, in other countries face higher costs for their equipment inputs relative to the U.S. semiconductor industry. TSMC's having to reduce its output increases its costs while the U.S. industry enjoys a reduction to its costs by producing more with inputs made cheap only by the export restriction on equipment.

The conundrum confronting national export control policy and international cooperation is now clear. Export controls for legitimate national security reasons can be the first-best policy to attack the problem at exactly its source and provide benefits to allies. But export controls can also be misused as a beggar-thy-neighbor policy to redistribute economic wellbeing, even from one ally to another.

Trading partners may be suspicious that the real motive for the policy is economic if there is an informational asymmetry as to whether the national security threat is legitimate. Information asymmetries may be difficult to overcome if it is hard to foresee all of a technology's potential (nefarious) uses at the time the good is traded, or if the full details of the adversarial threat can't be revealed to protect the source of the information. Suspicions are also heightened after the excuse has been abused, as when the Trump administration imposed national security tariffs on steel in 2018.

Thus, just as there is a need to multilateralize legitimate export controls, there are economic efficiency gains to agreeing to international rules so that governments cooperate and do not impose excessive and reciprocal export restrictions when national security threats are not present. Without such rules to guide policy, the noncooperative outcome could prevail: one country limits its exports (and imposes costs on partners), and other countries do the same (imposing reciprocal costs). This is the classic prisoner's dilemma in which all are made worse off relative to cooperation.

\section{THE WTO RULES AND EXPORT CONTROLS}

In addition to unilateral and multilateral export controls, governments have developed international rules that help limit the imposition of beggarthy-neighbor policies for economic or redistributive gain. A number of rules in this vein, as well as exceptions for permissible export restrictions, are set out under the World Trade Organization (WTO). The WTO has also 
provided a forum for dispute resolution when inevitable trade frictions arose. ${ }^{51}$ However, the WTO has only begun to face the challenges of interactions between trade, national security exceptions, and export controls.

The WTO came into effect in 1995, building on its predecessor, the GATT. A contemporary of COCOM, the GATT established the initial multilateral rulebook for national commercial policies affecting exports and imports following the Second World War.

The WTO treats the two main export policies - taxes and quotas - quite differently, albeit in parallel to its treatment of import-restricting policies. Countries are generally prevented from exercising export restrictions in the form of quotas or bans. Just as the WTO frowns on quantitative import limits, export quotas are discouraged under GATT Article XI. Export taxes, on the other hand, are broadly permissible under the WTO, similar to the preference for import tariffs over import quotas. Export taxes must also be implemented on a non-discriminatory basis and are thus subject to the WTO's most favored nation (MFN) rule. ${ }^{52}$

There are important exceptions. One is GATT Article XXI, which allowed a broad carve-out for "security exceptions." When imposing export controls, as long as countries respected the spirit of Article XXI, matters addressed by COCOM did not generally come up under the GATT. A second involves Article XI(1), which allows for "[e]xport prohibitions or restrictions temporarily applied to prevent or relieve critical shortages of foodstuffs or other products essential to the exporting contracting party." This would presumably serve as the justification adopted by a country challenged to explain its export restriction on food staples imposed during the commodity price spike of 2008-11, or on medical supplies during the COVID-19 pandemic. $^{53}$

51. For a discussion of the WTO's current dispute settlement status, see Bown \& Keynes, supra note 39.

52. See Petros C. Mavroidis, 1 The Regulation of International Trade 87-89 (2016) (discussing export taxes under the GATT and WTO); see also Mark Wu, Export Taxes, in HANDBOOK of DeEP TRADE AgreEments (Aaditya Mattoo, Nadia Rocha and Michele Ruta eds.) (forthcoming) (discussing export tax commitments countries have undertaken as part of preferential trade agreements).

53. The U.S. export controls of April 2020 on medical gear were imposed under the Defense Production Act and not the ECTA. See Chad P. Bown, COVID-19: Trump's Curbs on Exports of Medical Gear Put Americans and Others at Risk, PIIE (Apr. 9, 2020), https://www.piie.com/blogs/trade-andinvestment-policy-watch/covid-19-trumps-curbs-exports-medical-gear-put-americans-and. See also Chad P. Bown, EU Limits on Medical Gear Exports Put Poor Countries and Europeans at Risk, PIIE (Mar. 19, 2020), https://www.piie.com/blogs/trade-and-investment-policy-watch/eu-limits-medicalgear-exports-put-poor-countries-and (discussing the adverse impact of European Union trade limits on medical supplies for European nations); Girordani et al., Food Prices and the Multiplier Effect of Trade Policy 2-5 (IMF, Working Paper No. 14/182, 2014), https://www.imf.org/ en/Publications/WP/Issues/2016/12/31/Food-Prices-and-the-Multiplier-Effect-of-Trade-Policy-42374 (discussing factors that lead to food price spikes); Soumaya Keynes, New Trade Barriers Could Hamper 
One crucial difference between export taxes and import tariffs is that few countries have taken on legal commitments at the WTO to constrain how high their export taxes might go. For decades starting in 1947, countries negotiated rounds of reductions to their import tariffs and then agreed to schedule (bind) them, legally promising not to raise them above a certain level. For the most part, governments have not made similar promises about their export taxes under the GATT or WTO. ${ }^{54}$ There are a few exceptions, with China being the most significant. China committed to schedule and bind its export taxes when it acceded to the WTO in 2001.

\section{WTO DISPUTE SETTLEMENT, NATIONAL SECURITY, AND EXPORT RESTRICTIONS}

In addition to its rules, a second main function of the WTO historically has been to provide a forum to resolve commercial disputes between members. ${ }^{55}$ Because countries have political and economic incentives to impose export restrictions unilaterally, some frictions over such policies were inevitable.

Nevertheless, there have been very few documented cases in which a government imposed an export control, faced a WTO dispute, and used national security as a defense. One example is the WTO dispute over Japan's more stringent controls on exports to South Korea in 2019. Japan suddenly made Wassenaar Arrangement-controlled fluorinated polyimide, resist polymers, and hydrogen fluoride-inputs used to make products like smartphones, television displays, and semiconductors - subject to license requirements for sale to South Korea. ${ }^{56}$

the Supply of Masks and Medicines, THE ECONOMIST (Mar. 11, 2020), https://www.economist.com/ finance-and-economics/2020/03/11/new-trade-barriers-could-hamper-the-supply-of-masks-and-

medicines (discussing the impact of trade marries on medical suppliers); Will Martin \& Kym Anderson, Export Restrictions and Price Insulation During Commodity Price Booms 2 (IMF, Policy Research Working Paper No. 5645), https://www.imf.org/external/np/seminars/eng/ 2011/trade/pdf/session1martin-paper.pdf (discussing the impact of market-insulating policy behavior on international price spikes for farm commodities).

54. The United States does not generally implement export taxes as they are banned under U.S. CONST. art. I, § 9, cl. 5 .

55. WTO dispute settlement is under separate challenge, due to the Trump administration's refusal to allow the appointment of new members to its Appellate Body. Bown \& Keynes, supra note 39, at 23. While important, these additional institutional challenges will not be of focus here.

56. See, e. g., Wassenaar Arrangement on Export Controls for Conventional Arms and Dual-Use Goods and Technologies Public Documents, Volume II List of Dual-Use Goods and Technologies and Munitions List, WA-List (18) 4-17, 73, 128 (Dec. 2018), https://www.wassenaar.org/ app/uploads/2019/consolidated/WA-DOC-18-PUB-001-Public-Docs-Vol-II-2018-List-of-DU-Goodsand-Technologies-and-Munitions-List-Dec-18.pdf (listing specifications for dual-use goods and technologies). Prior to Japan's action, South Korea was on a white list of countries wherein such shipments did not require an individual license. 
South Korea quickly filed a WTO dispute; in its view, Japan's action did not arise from an increased national security threat, but was simply retribution for a diplomatic flare-up involving reparations for Japanese mistreatment of South Koreans during the Second World War. At the time of writing, the WTO dispute was still in process. If it moves forward, Japan may claim that its export controls arose after a threat to its national security, justifying its actions under an Article XXI defense. ${ }^{57}$

There have even been few WTO disputes in which countries adopted the national security defense for challenges to their import-restricting policies. The only case to have reached a legal decision involved Russia, which used the justification when Ukraine challenged trade barriers imposed during the military conflict between the two countries. ${ }^{58}$ There are other such defenses in the pipeline, however, including a number of challenges to the Trump administration's tariffs on steel and aluminum imposed in 2018. ${ }^{59}$

There have been three main reasons behind the limited number of formal WTO disputes involving a country's national security: Countries were hesitant to impose trade restrictions in the name of national security, trading partners were hesitant to file disputes in which that was the likely defense, and countries were hesitant to invoke the defense if challenged. These three hesitations arose out of recognition that the WTO would be put in a lose-lose position if forced to rule on any country's national security defense. Striking down the measure would jeopardize the legitimacy of the WTO from one side - the WTO would be accused of threatening a member country's sovereignty. But upholding the measure meant attacks from the other side - countries would be free to invoke the defense over seemingly anything, rendering meaningless even the most basic WTO rules. ${ }^{60}$

Unrelated to national security, countries have made some WTO challenges to the beggar-thy-neighbor effects of trading partners' export

57. See Request for Consultation by the Republic of Korea, Japan-Measures Related to the Exportation of Products and Technology to Korea, WTO Doc. WT/DS590/1 (Sept. 16, 2019), https://www.mofa.go.jp/mofaj/files/000549089.pdf (discussing initiation of South Korea-Japan WTO dispute). 2019).

58. See Panel Report, Russia-Measures Concerning Traffic in Transit, WT/DS512/R (May 4,

59. Request for Consultations by the European Union, United States-Certain Measures on Steel and Aluminum Products, WTO Doc. WT/SD547/1 (June 6, 2018), https://docs.wto.org/dol2fe/ Pages/FE_Search/FE_S_S009DP.aspx?language $=$ E\&CatalogueIdList $=246115,246118,246147,246155$, $246044,246024,245912,245759 \&$ CurrentCatalogueIdIndex $=7 \&$ FullTextHash $=\& H a s E n g l i s h R e c o r d=\operatorname{Tr}$ ue \&HasFrenchRecord $=$ True \&HasSpanishRecord $=$ True.

60. Pinchis-Paulsen notes these and related concerns that arose during the original GATT negotiations in the 1940s that resulted in Article XXI. Mona Pinchis-Paulsen, Trade Multilateralism and U.S. National Security: The Making of the GATT Security Exceptions, 41 MicH. J. INT'L 109, 123-130 (2020). 
restrictions. China has faced the most disputes, in part because it has taken on the most commitments over limiting its export restrictions. Japan, the United States, and the European Union, for example, felt the brunt of China's export restraints on rare earth elements and brought a dispute in 2012. At the time, China provided ninety-seven percent of the world's supply of elements of critical importance for both renewable energies and the defense industry. ${ }^{61}$ But countries have been concerned about the negative impact on their industries of other Chinese export restrictions, including some on raw materials and primary aluminum. By limiting exports strategically, Beijing was providing unfair advantages to Chinese manufacturing-which relied on inputs made cheap locally because of the restrictions - that caused harm to foreign competitors. ${ }^{62}$

Because most other WTO members have fewer legal obligations, there was less constraint on their use of export restrictions and thus there were fewer disputes. Nevertheless, some cases have arisen. In the late 1990s, out of concern for its manufacturers of footwear, automotive seating, and other leather-consuming industries, the European Union challenged Argentina, Pakistan, and India for their limits on cowhide and leather exports. ${ }^{63}$

In a few instances, disputes arose when countries were too aggressive at countering the beggar-thy-neighbor effects of the export restrictions unilaterally. Consider Indonesia's export tax for palm oil and Argentina's

61. Wayne M. Morrison \& Rachel Tang, Cong. Res. Serv., China's Rare Earth Industry and Export Regime: Economic and Trade Implications for the United States 1 (2012), https://fas.org/sgp/crs/row/ R42510.pdf; Eric W. Bond \& Joel Trachtman, China-Rare Earths: Export Restrictions and the Limits of Textual Interpretation, 15 World Trade Rev. 189, 191 (2016).

62. See Request for the Establishment of a Panel by the United States, China-Export Duties on Certain Raw Materials, 2, 5, WTO Doc. WT/DS508/6 (Oct. 14, 2016) (discussing China's alleged failure to comply with its WTO obligations); Appellate Body Report, China-Measures Related to the Exportation of Various Raw Materials, 2, WTO Doc. WT/DS394/AB/R (adopted Feb. 22, 2012), https://www.wto.org/english/tratop_e/dispu_e/394_395_398abr_e.pdf (discussing China's alleged failure to comply with its WTO obligations). According to OECD, supra note 20, China's downstream aluminum manufacturing has benefited from implicit subsidies resulting from its export restrictions on primary aluminum. Thus, this would likely have also been an issue in Request for Consultations by the United States, China-Subsidies to Producers of Primary Aluminum, WTO Doc. WT/DS519/1 (Jan. 17, 2017), which the Obama administration filed at the very end of its administration but which the Trump administration did not actively pursue.

63. Panel Report, Argentina-Measures Affecting the Export of Bovine Hides and the Import of Finished Leather, WTO Doc. WT/DS155/R (adopted Feb. 16, 2001), https://ocs.wto.org/ dol2fe/Pages/FE_Search/FE_S_S006.aspx?Query=(@Symbol=\%20wt/ds155/r*\%20not\%20rw*)\&Lang uage $=$ ENGLISH\&Context $=$ FomerScriptedSearch\&languageUIChanged=true\#; Request for the Establishment of a Panel by the European Communities, India-Measures Affecting Export of Certain Commodities, WTO Doc. WT/DS120/2 (Oct. 13, 2000); Request for Consultations by the European Communities, Pakistan —Export Measures Affecting Hides and Skins, WTO Doc. WT/DS107/1 (Nov. 20, 1997). 
export tax for soybeans. ${ }^{64}$ The economic effect was that each country provided an implicit subsidy to its downstream biodiesel industry, which the European Union targeted with countervailing and antidumping duties. Indonesia and Argentina challenged the E.U. trade remedies targeting the export restrictions, but the restrictions went unaddressed in Geneva.

All told, the relatively limited frequency of trade disputes over export controls, export-restricting policies, and invocations of the national security justification could change. Certainly a U.S. policy decision to impose additional export controls for dual-use technologies would likely bump up against other U.S. commitments in international agreements, including those at the WTO, and lead to more of such frictions. Given the extreme political sensitivity of such cases and those who would point to this as an erosion of national sovereignty, the multilateral trading system may need to contemplate new means of resolving such frictions.

\section{CONCLUSION}

Much of 2017-20 found the Trump administration debating and then imposing tariffs under the justification that imports, as well as China itself, posed a threat to America's national security. Somewhat less public was a concomitant, but perhaps more politically bipartisan, potential shift of U.S. export policy. Though the exact direction of U.S. export control policy remains uncertain, farther-reaching government restrictions on foreign sales of American-made goods and services seem likely.

Exports pose a more distinct national security threat than imports. And how to effectively restrain American exports presented a number of different policy challenges - domestically, in the Wassenaar Arrangement, and even at the WTO. Furthermore, any sudden policy shift would lead to both shortand long-run costs for the U.S. economy. In the interim, lingering policy uncertainty over future access to foreign markets may have crimped U.S. investment in $R \& D$ and imposed separate costs of its own.

New conflicts between the United States and its allies also seemed likely to emerge in the struggle to align export controls, because of divergent commercial interests. Cooperation was hindered by increased international skepticism - fed by American abuse of the national security justificationthat countries were acting without their national security actually being under threat. With the existing multilateral framework for adopting export

64. For a discussion, see Carolyn Fischer \& Timothy Meyer, Baptists and Bootleggers in the Biodiesel Trade: EU-Biodiesel (Indonesia) (forthcoming 2020); Appellate Body Report, European Union-Anti-Dumping Measures on Biodiesel from Argentina, WTO Doc. WT/DS473/AB/R (Oct. 6, 2016); Panel Report, European Union-Anti-Dumping on Biodiesel from Indonesia, WTO Doc. WT/DS480/R (March 1, 2018). 
controls the legacy of an earlier era, a result could be more trade frictions sent to the WTO - a multilateral institution both without much experience resolving these types of disputes and already attacked by the U.S. administration.

As of the time of writing, U.S. export policy was still a work in progress. Major unknowns included how American's own list-review regulatory process would evolve, as well as whether and how successful the United States would be at getting allies to adopt similar controls multilaterally. What is clear is that failure to strike the balance between protecting national security and minimizing negative commercial consequences would be costly for the U.S. economy, ineffective at addressing national security risks, and problematic for trade and diplomatic relations. 